\title{
UPAYA MENINGKATKAN KEMAMPUAN PENALARAN MATEMATIS SISWA MENGGUNAKAN PEMBELAJARAN MODEL LEARNING CYCLE 7E (LC 7E) PADA POKOK BAHASAN PENYAJIAN DATA DAN PELUANG DI KELAS X MIA-1 SMA NEGERI 9 JAKARTA
}

\author{
Yulita Venesia, Anton Noornia, Tri Murdiyanto \\ Program Studi Pendidikan Matematika, FMIPA UNJ
}

\begin{abstract}
Abstrak
Penelitian ini bertujuan untuk meningkatkan kemampuan penalaran matematis siswa pada pokok bahasan penyajian data dan peluang di kelas X MIA-1 SMA Negeri 9 Jakarta melalui pembelajaran menggunakan model learning cycle $7 e$. berdasarkan hasil observasi dan hasil tes prapenelitian kemampuan penalaran matematis siswa yang dilakukan di kelas X MIA-1 SMA Negeri 9 Jakarta menunjukan bahwa kemampuan penalaran matematis siswa termasuk kategori rendah, yaitu 31,44 dari nilai maksimal 100. Oleh karena itu, diperlukan upaya untuk meningkatkan kemampuan penalaran matematis siswa. Salah satu upaya untuk mengatasi masalah pembelajaran yang terjadi ialah dengan menerapkan pembelajaran model learning cycle 7e. Model learning cycle terdiri dari 7 tahap yaitu elicit, engage, explore, explain, elaborate, evaluate dan extend, masingmasing tahapan dapat meningkatkan kemampuan penalaran matematis siswa dalam proses pembelajaran.

Penelitian ini merupakan penelitian tindakan kelas (classroom action research) yang dilaksanakan dalam tiga siklus dan setiap siklus terdiri dari empat tahapan yaitu perencanaan, pelaksanaan, analisis dan refleksi. Setiap siklus menggunakan pembelajaran model learning cycle $7 e$. Siswa juga diberikan tes akhir pada setiap siklus untuk mengukur peningkatan kemampuan penalaran matematis siswa. Penelitian ini berlangsung dari bulan April hingga Mei 2016 di kelas X MIA-1 SMA Negeri 9 Jakarta tahun ajaran 2015/1016 dengan jumlah siswa 36 orang.

Hasil penelitian menunjukan bahwa pembelajaran matematika menggunakan model learning cycle $7 e$ dapat meningkatkan kemampuan penalaran matematis siswa pada materi penyajian data dan peluang. Hal tersebut ditunjukan berdasarkan hasil pengamatan pada aktivitas pembelajaran matematika dengan model learning cycle $7 e$. selain itu, meningkatkan kemampuan penalaran matematis siswa ditunjukan dengan adanya peningkatan nilai rata-rata tes akhir siklus. Rata-rata nilai tes akhir kemampuan penalaran matematis siswa kelas X MIA-1 pada siklus I adalah 53,48 termasuk dalam kriteria C+, kemudian pada siklus II meningkat menjadi 68,03 termasuk dalam kriteria B dan pada siklus III meningkat menjadi 80,22 termasuk dalam kriteria B+. Kemudian jumlah siswa dengan nilai kemampuan penalaran matematis mencapai atau melebihi 75 juga mengalami peningkatan. Siklus I sebanyak $10,34 \%$ siswa, pada siklus II meningkat menjadi $24,24 \%$ siswa dan pada siklus III meningkat menjadi $84,37 \%$ siswa.
\end{abstract}

Kata kunci: Kemampuan Penalaran Matematis, Pembelajaran Model Learning Cycle 7e

\section{PENDAHULUAN}

A. Latar Belakang

Belajar matematika membutuhkan keterampilan dan keahlian yang baik dalam mencari solusi. Jika seorang siswa tidak terbiasa dalam menyelesaikan soal matematika maka ia mengalami kesulitan dalam belajar matematika. Salah satu tujuan pembelajaran matematika yaitu agar siswa dapat memiliki kemampuan penalaran. Pola berfikir yang dikembangkan oleh matematika akan melatih siswa untuk dapat menarik kesimpulan terhadap suatu fakta dan hal tersebut membutuhkan suatu kemampuan penalaran matematis yang seharusnya sudah tertanam dalam diri setiap siswa. Penalaran matematis membentuk dasar dari suatu pemahaman matematis. Oleh karena itu, pemahaman matematis bergantung pada penalaran dan penalaran sangat penting untuk siswa dalam menumbuhkan pengetahuan matematikanya.

Berdasarkan observasi, wawancara, dan tes prapenelitian yang dilakukan di kelas X MIA-1 SMA Negeri 9 Jakarta, diperoleh hasil bahwa Siswa hanya mampu mengerjakan soal yang sesuai dengan contoh yang diberikan guru maupun yang terdapat dalam buku teks, apabila soal 
yang diberikan berbeda dari yang dicontohkan maka sebagian besar siswa akan kebingungan dan cenderung tidak bisa mengerjakan.

Tahapan selanjutnya diberikan tes kepada 36 siswa kelas X MIA-1, untuk mengetahui seberapa tinggi tingkat kemampuan penalaran matematis siswa kelas X MIA-1. Materi yang diujikan terdiri dari 4 butir yang masing-masing soal terdiri dari satu indikator kemampuan penalaran matematis. Hasil rata-rata tes pra penelitian siswa kelas X MIA-1 yaitu 31,4, oleh karena itu dapat disimpulkan bahwa kemampuan penalaran matematis siswa kelas X MIA-1 masih sangat kurang dan perlu ditingkatkan.

Salah satu faktor yang dapat meningkatkan kemampuan penalaran matematis siswa ialah dalam proses pembelajaran matematika. Guru sebagai pendidik perlu memberikan variasi dalam proses pembelajaran misalkan melalui penerapan model pembelajaran yaitu learning cycle $7 e$. Model ini terdiri dari tujuh fase yaitu elicit, engage, explore, explain, elaborate, evaluate and extend.

Pembelajaran matematika dengan model learning cycle $7 \mathrm{e}$ diharmatapkan dapat meningkatkan kemampuan penalaran matematis siswa. Jadi, penelitian ini mengenai "Upaya Meningkatkan Kemampuan Penalaran Matematis Siswa Menggunakan Pembelajaran Model Learning Cycle 7E (LC 7E) pada Pokok Bahasan Penyajian Data dan Peluang di Kelas X MIA1 SMA Negeri 9 Jakarta."

\section{B. Fokus Penelitian}

Berdasarkan latar belakang masalah yang telah di uraikan di atas, fokus dari penelitian ini adalah upaya meningkatkan kemampuan penalaran matematis siswa melalui model pembelajaran learning cycle $7 e \quad(l c 7 e)$. Berdasarkan fokus penelitian di atas, di ajukan pertanyaan yang akan terjawab setelah melakukan penelitian, yaitu: Bagaimana penerapan model learning cycle $7 e$ dapat meningkatkan kemampuan penalaran matematis siswa?

\section{Tujuan Penelitian}

penelitian ini bertujuan untuk meningkatkan kemampuan penalaran matematis siswa kelas X MIA-1 SMAN 9 Jakarta menggunakan model pembelajaran learning cycle $7 e$

\section{Manfaat Penelitian}

1. Bagi siswa, khususnya kelas $X$ MIA-1 SMAN 9 Jakarta diharapkan siswa lebih aktif dalam proses pembelajaran dan mampu meningkatkan kemampuan penalaran matematis.

2. Bagi guru, khususnya guru matematika kelas X MIA-1 SMAN 9 Jakarta, sebagai masukan untuk memperluas wawasannya dan meningkatkan kemampuannya dalam mengembangkan metode pembelajaran matematika lebih kreatif dan inovatif yang disesuaikan dengan kebutuhan pembelajaran di kelas.

3. Bagi sekolah SMA Negeri 9 Jakarta, penelitian ini diharapkan sebagai informasi untuk memperbaiki kualitas sekolah dan sebagai sumbangan pemikiran untuk meningkatkan kualitas pendidikan khususnya matematika.

\section{KAJIAN PUSTAKA}

A. Deskripsi Teoritis

\section{Pembelajaran Matematika}

Pembelajaran ialah suatu kombinasi yang tersusun dari unsur manusiawi, material, fasilitas, perlengkapan, dan prosedur yang saling mempengaruhi untuk mencapai tujuan pembelajaran (Hamalik, 2009). matematika dikenal sebagai pengetahuan yang terstruktur dan sistematis dalam arti bagian-bagian matematika tersusun secara hirarkis dan terjalin dalam hubungan fungsional yang erat. (dalam Riyanto, 2011). Pembelajaran matematika ialah serangkaian peristiwa yang mempengaruhi perubahan tingkah laku peserta didik untuk mendapatkan pengetahuan yang terstruktur dan sistematis.

\section{Penalaran Matematis}

penalaran merupakan suatu kegiatan, suatu proses atau suatu aktifitas berpikir untuk menarik kesimpulan atau membuat suatu pernyataan baru yang benar berdasarkan pada 
beberapa pernyataan yang kebenarannya telah dibuktikan atau dirumuskan sebelumnya (Shadiq, 2004). Math Glossary (dalam Enika, 2011) mathematical reasoning thinking through math problems logically in order to arrive at solutions. It involves being to identify what is important and unimportant in solving a problem and to explaine or justify a solution".

Terdapat dua macam penalaran, yaitu penalaran deduktif dan penalaran induktif. Perbedaan penalaran induktif dan deduktif dilihat dari cara menarik kesimpulan. Wardhani mengatakan bahwa siswa dikatakan menguasai kemampuan penalaran matematis apabila mampu menggunakan penalaran pada pola dan sifat, melakukan manipulasi matematika dalam membuat generalisasi, menyusun bukti, atau menjelaskan gagasan dan pernyataan matematika.(Wardhani, 2008).

Pada penelitian ini, peneliti menggunakan indikator kemampuan penalaran matematis menurut Peraturan Dirjen Dikdasmen Depdiknas No. 506/C/PP/2004 (dalam Wardhani, 2008), yaitu: (a) mengajukan dugaan; (b) melakukan manipulasi matematika; (c) menarik kesimpulan, menyusun bukti, memberikan alasan atau bukti terhadap beberapa solusi; (d) menarik kesimpulan dari pernyataan; (e) memeriksa kesahihan suatu argumen; serta (f) menemukan pola atau sifat dari gejala matematis untuk membuat generalisasi.

\section{Model Learning Cycle $7 E$}

Model pembelajaran learning cycle awalnya hanya terdiri dari tiga fase kemudian perkembangan berkembang menjadi $5 E$ hingga learning cycle berkembang kembali menjadi tujuh fase.yaitu Elicit, Engage, Explore, Explain, Elaborate, Evaluate, dan Extend.

Fase elicit, yaitu fase ini pentingnya guru menimbulkan pemahan awal siswa dan memastikan apa saja yang siswa ketahui sebelum pembelajaran dimulai. Fase ini dapat diterapkan guru dengan memberikan pertanyaan-pertanyaan mendasar yang berhubungan dengan materi yang akan dipelajarari. Pada fase ini guru hanya memancing rasa ingin tahu siswa saja (Einsekraft, 2003).

Fase engage, fase ini dimaksudkan untuk menarik perhatian siswa, merangsang kemampuan berfikir siswa serta membangkitkan ketertarikan dan motivasi siswa terhadap materi yang diajarkan (Einsekraft, 2003).

Fase explore, siswa diberikan kesempatan untuk bekerja sama tanpa arahan langsung dari guru dalam bentuk kelompok-kelompok kecil. Siswa didorong untuk dapat mengamati, merekam data, menafsirkan hasil, mengembangkan hipotesis dan merencanakan eksperimen. Siswa akan memperoleh penge- tahuannya sendiri dan pengalamannya dalam materi yang sedang diajarkan (Einsekraft, 2003).

Fase explaine, pada fase ini siswa diperkenalkan dengan konsep, hukum dan teori baru. Siswa menyimpulkan dan menjelaskan temuannya pada fase sebelumnya (eksplore).

Fase elaborate, Fase ini bertujuan untuk membawa siswa menerapkan simbol-simbol, definisidefinisi, konsep-konsep dan keterampilan-keterampilan yang telah diperoleh pada fase sebelumnya pada permasalahan-permasalahan yang berkaitan dengan contoh dari materi yang dipelajari (Einsekraft, 2003).

Fase evaluate dari hasil pembelajaran yang telah dilakukan dapat dijadikan strategi penilaian formal dan informal. Guru diharapkan secara terus menerus dapat mengobservasi dan memperhatikan siswa terhadap kemampuan dan keterampilannya. Selain itu, guru juga mendapatkan umpan balik dari hasil siswa dan dapat memodifikasi strategi pengajaran mereka untuk siklus berikutnya (Einsekraft, 2003).

Fase extend, Fase ini secara eksplisit mengingatkan guru pentingnya bagi siswa untuk berlatih menstransfer ilmu yang sudah ia dapatkan kepada orang lain. Guru memastikan bahwa siswa menerapkan pengetahuan yang telah didapat pada konteks baru (Einsekraft, 2003).

\section{Penyajian Data dan Peluang}

Data dalam ukuran besar perlu menyajikannya sedemikian sehingga agar mudah diamati atau diposes. Data dalam disajikan dalam bentuk tabel frekuensi, diagram batang, diagram lingkaran, diagram garis dan lain-lain.

Peluang adalah besarnya kemungkinan terjadinya sebuah kejadian dapat ditulis sebagai $p=\frac{n(K)}{n(S)}$. Dimana: Dimana : $\mathrm{P}(\mathrm{K})=$ Peluang, $\mathrm{n}(\mathrm{K})=$ banyaknya kejadian dan (S) = banyaknya ruang sampel. 


\section{B. Penelitian yang Relevan}

Penelitian yang dilakuka oleh Pitriati dengan judul "Pengaruh Penerapan Model Learning Cycle 7E Terhadap Peningkatan Kemampuan Penalaran dan Kemampuan Komunikasi Matematis Siswa SMP "menyatakan bahwa kemampuan penalaran matematis siswa mengalami peningkatan selama dalam proses pembelajaran guru menerapkan model learning cycle $7 e$ dan kemampuan penalaran matematis siswa yang mengikuti pembelajaran dengan model learning cycle $7 e$ lebih baik dari pada kemampuan penalaran matematis siswa yang mengikuti pembelajaran secara konvensional.

\section{Kerangka Berfikir}

Penalaran merupakan aspek vital dalam matematika. Salah satu tujuan dalam pembelajaran matematika yang ingin diwujudkan oleh pemerintah yaitu mengembangkan penalaran matematis pada diri setiap siswa. Kemampuan penalaran diperlukan siswa untuk memahami konsep untuk selanjutnya menyelesaikan permasalahan matematika. Namun pada kenyataannya kemampuan penalaran siswa khususnya siswa sekolah menengah atas masih terbilang cukup rendah. Hal ini dikarenakan guru tidak melibatkan siswa secara aktif dalam proses pembelajaran matematika di sekolah sehingga tidak mendukung terjadinya proses berpikir, bernalar, dan melibatkan siswa secara aktif dalam pengalaman belajarnya.

Berdasarkan observasi yang dilakukan di kelas X MIA-1 SMA Negeri 9 Jakarta menunjukan bahwa kemampuan penalaran matematis siswa pada kelas ini masih rendah dan perlu ditingkatkan. Melihat kenyataan tersebut salah satu upaya untuk memecahkan permasalah di atas yaitu dengan memberikan pembelajaran matematika berbasis konstruktivisme yaitu learning cycle yang terdiri dari 7 fase yaitu elicit, engage, explore, explain, elaborate, evaluate, dan extend. Model learning cycle $7 e$ merupakan pembelajaran yang terpusat pada siswa (student centered learning) dengan berperan aktif dalam menggali dan memperkaya pemahaman mereka terhadap konsep-konsep yang dipelajari. Sehingga hasil yang diharapkan motivasi dan minat belajar siswa meningkat, suasana pembelajaran menyenangkan, keaktifan siswa meningkat dan hal ini akan membuat hasil belajar siswa meningkat.

\section{Hipotesis Tindakan}

Hipotesis tindakan dalam penelitian ini ada peningkatan kemampuan penalaran matematis siswa di kelas X MIA-1 SMA Negeri 9 Jakarta setelah mengikuti pembelajaran matematika melalui model pembelajaran learning cycle $7 e$.

\section{Metodologi Penelitian}

\section{A. Tujuan Khusus Penelitian}

Penelitian ini secara khusus bertujuan untuk meningkatkan kemampuan penalaran matematis siswa menggunakan pembelajaran model learning cycle $7 e$ (lc $7 e$ ) pada pokok bahasan penyajian data dan peluang di Kelas X MIA-1 SMA Negeri 9 Jakarta.

\section{B. Pendekatan dan Jenis Penelitian}

Penelitian ini menggunakan pendekatan kualitatif. Jenis penelitian ini adalah jenis penelitian tindakan kelas. Berdasarkan berbagai pengertian penelitian tindakan kelas, Kunandar menyimpulkan bahwa PTK (action research) adalah penelitian tindakan yang dilakukan dengan tujuan memperbaiki mutu praktik pembelajaran di kelas. Penelitian ini dilakukan oleh guru yang sekaligus sebagai peneliti di kelasnya atau bersama-sama dengan orang lain (kolaborasi). Menurut Lewin (dalam Wijaya dan Dedi, 2010) empat aspek pokok dalam penelitian Tindakan Kelas (PTK) yaitu: perencanaan (planning), tindakan (acting), pengamatan (observing) dan refleksi (reflecting).

\section{Kehadiran Peneliti dan Lokasi Penelitian}

Kehadiran peneliti dituntut selama proses penelitian berlangsung karena proses pengumpulan data dilakukan dalam situasi yang sesungguhnya. Penelitian ini melibatkan guru sebagai peneliti utama yang melaksanakan penelitian model pembelajaran learning cycle $7 e$ 
yang telah dirancang bersama. Guru tersebut adalah guru matematika dari kelas penelitian. Pengamat (observer) juga dilibatkan membantu peneliti dalam proses pengamatan belajar di kelas penelitian, sekaligus menjadi instrumen guna menguji keabsahan data. untuk membantu selama proses pengamatan di kelas maka jumlah pengamat (observer) ditambah dua orang. Oleh karena itu observer di kelas penelitian berjumlah tiga orang.

Penelitian ini akan dilakukan di SMA Negeri 9 Jakarta yang berlokasi di Jl. SMA 9 Halim, Jakarta Timur. Penelitian ini dilakukan kepada seluruh siswa kelas MIA-1 SMAN 9 Jakarta yang berjumlah 36 siswa.

\section{Data dan Sumber Data}

Sumber data pada penelitian ini adalah siswa kelas X MIA-1 SMAN 9 Jakarta yang berjumlah 36 siswa tetapi hanya enam orang siswa yang dijadikan subjek penelitian. Jenis data yang dikumpulkan dalam penelitian ini yaitu berupa data kuantitatif dan kualitatif, data kuantitatif berupa hasil tes prapenelitian dan hasil tes tiap akhir siklus dan data kualitatif berupa data hasil pengamatan setiap siklus, catatan lapangan selama pembelajaran berlangsung, dan hasil wawancara.

\section{E. Subjek Penelitian dan Instrumen Penelitian}

Subjek Penelitian ini dilakukan terhadap siswa kelas X MIA-1 SMA Negeri 9 Jakarta yang berjumlah 36 siswa. Namun karena keterbatasan peneliti dalam melakukan pengamatan maka dipilih enam orang siswa yang memiliki kemampuan berbeda. Subyek peneliti terdiri atas dua orang siswa kelompok atas, dua orang siswa kelompok menengah dan dua orang lagi dari kelompok bawah. Instrumen yang digunakan untuk mengumpulkan data pada penelitian ini, antara lain:

a. Soal tes kemampuan awal penalaran matematis

b. Soal tes kemampuan penalaran matematis pada setiap akhir siklus

c. Tabel aktivitas

d. Alat dokumentasi

e. Observer

f. Lembar catatan lapangan

\section{F. Teknik Pengumpulan Data}

Data tes prapenelitian diperoleh dari hasil tes yang diberikan participant observer sebelum penelitian dimulai.Data kemampuan penalaran matematis diperoleh dari setiap siklus. Soal yang diberikan merupakan soal uraian yang berkaitan dengan materi yang telah diberikan.Data hasil pengamatan dan catatan lapangan setiap siklus yang diperoleh pada saat pembelajaran berlangsung.Data hasil wawancara diperoleh dari hasil rekaman wawancara yang bersumber dari siswa.Dokumentasi aktivitas siswa diambil pada setiap siklus dengan menggunakan handphone.

\section{G. Validitas Data}

Validitas data dilakukan untuk meyakinkan bahwa data yang diperoleh benar dan valid. Tehnik yang digunakan pada penelitian ini ialah Triangulasi Teknik triangulasi yang digunakan dalam penelitian ini ialah triangulasi sumber. Teknik triangulasi sumber merupakan pengecekan keabsahan data melalui informasi yang diberikan oleh sumber yang berbeda-beda yaitu guru, siswa dan observer. Penelitian ini pada pelaksanaan pembelajaran matematika menggunakan model pembelajaran learning cycle 7e di kelas X MIA-1 SMA Negeri 9 Jakarta akan divalidasi dengan menggunakan cara membandingkan hasil wawancara dan hasil observasi pengamat lain.

\section{H. Analisis Data}

Melakukan analisis data bearti melakukan kajian untuk memahami struktur suatu fenomena-fenomena yang berlaku di lapangan. Analisis data dalam PTK bisa dilakukan dengan analisis kualitatif dan analisis kuantitatif. Analisis data dalam PTK diarahkan untuk mencari 
dan menemukan upaya yang dilakuakan guru dalam meningkatkan kualitas proses dan hasil belajar siswa.

Analisis data dilakukan melalui tiga tahap. Pertama mereduksi data, yaitu kegiatan untuk menyeleksi data yang sesuai dengan fokus permasalahan. Kedua mendeskripsikan data sehingga data yang telah terkumpul menjadi bermakna. Tahap ketiga yaitu membuat kesimpulan berdasarkan deskripsi data. analisis data dilakukan setiap siklus berlangsung. Data yang diperoleh berupa hasil kerja siswa, catatan lapangan yang berupa hasil wawancara dan tablel aktivitas siswa yang diubah menjadi kalimat-kalimat yang bermakna ilmiah.

\section{Tahap-tahap Penelitian}

Penelitian dimulai dengan melakukan kegiatan prapenelitian bulan 7 Septemeber 2015. Kegiatan prasiklus pada tanggal 14 April 2016, kemudian dilanjutkan dengan kegiatan siklus I pada tanggal 19 dan 21 April 2016, siklus II pada tanggal 28 April dan 3 Mei 2016, dan siklus III pada tanggal 10 dan 12 Mei 2016.

\section{J. Desain Penelitian}

Desain penelitian dalam penelitian ini adalah prapenelitian, prasiklus, siklus I, siklus II, dan siklus III. Setiap siklus terdiri dari empat tahapan yaitu perencanaan, pelaksanaan, analisis, dan refleksi.

\section{K. Indikator Keberhasilan}

1. Secara umum rata-rata hasil tes enam siswa yang dijadikan subjek penelitian untuk meningkatkan kemampuan penalaran matematis siswa kelas X MIA-1 SMA Negeri 9 Jakarta setelah menerapkan model pembelajaran learning cycle $7 e$ mengalami peningkatan dan berada pada kriteria minimal yaitu B.

2. Minimal $75 \%$ siswa telah mencapai atau melebihi ketuntasan belajar minimal atau KKM sebesar 75 dan ada pada kriteria B.

\section{PAPARAN DATA, HASIL PENELITIAN, DAN PEMBAHASAN}

Berdasarkan hasil wawancara yang peneliti lakukan dengan subjek penelitian dan guru dikelas peneliti dapat disimpulkan bahwa pembelajaran matematika menggunakan model pembelajaran learning cycle $7 e$ membuat siswa lebih sering menggunakan kemampuan penalaran matematisnya dan membantu siswa untuk memahami materi yang sedang di pelajari. Hal tersebut juga dikemukakakn oleh guru bahwa pembelajaran menggunakan model pembelajaran learning cycle $7 e$ dapat mengasah kemampuan penalaran siswa untuk memahami konsep materi yang di pelajari.

Selama proses pembelajaran dengan model learning cycle $7 e$ di kelas X MIA-1 menunjukkan adanya peningkatan kemampuan penalaran matematis siswa pada setiap siklusnya, baik dilihat secara keseluruhan siswa kelas X MIA--1 maupun keenam subjek penelitian. Fase pertama yaitu eclicit dimana guru memfokuskan siswa terhadap materi yanag akan dipelajari. Guru menyelidiki kemampuan awal siswa dengan mengajukan beberapa pertanyaan kepada siswa terkait materi yang sudah siswa pelajari sebelumnya dikaitkan dengan kehidupan sehari-hari.

Tahap dalam learning cycle $7 e$ selanjutnya yaitu engage. Tahap ini meningkatkan siswa untuk indikator mengajukan dugaan karena pada fase ini selain siswa dilibatkan dalam kegiatan demonstrasi, diskusi dan eksperimen juga siswa diajarkan untuk berhipotesis dari masalah yang sedang di diskusikan. tahap ini dimanfaatkan untuk merangsang kemampuan berfikir siswa serta membangkitkan minat dan motivasi siswa terhadap materi yang akan di ajarkan.

Indikator menarik kesimpulan, menyusun bukti, memberikan alasan/bukti terhadap solusi ditingkatkan dalam tahap explore, Karena pada fase ini siswa diberikan kesempatan untuk mengamati, merekam data, dan menafsirkan hasil pada penelitiannya sehingga siswa dapat memberikan alasan/bukti terhadap solusi. Tahap ini menjadi tahap yang disenangi siswa karena siswa akan belajar berdasarkan penagalamannya atau aktivitasnya sendiri untuk mendapatkan pengetahuan yang baru.

Siswa dikatakan sudah menggunakan kemampuan penalarannya apabila dapat menarik kesimpulan dari pernyataan dan kemampuan ini ditingkatkan pada tahap explaine explaine 
sangat mendukung untuk indikator karena pada fase ini setelah siswa diperkenalkan dengan konsep, hukum dan teori baru, siswa akan menyimpulkan dan menjelaskan temuannya untuk persoalan yang sedang dihadapainya. Tahap ini menjadi lebih efektif pada saat guru meminta perwakilan masing-masing kelompok untuk menempelkan hasil pengerjaan LAS mereka di papan tulis.

Kemampuan manipulasi matematika siswa meningkatkan ketika siswa ada pada tahap elaborate karena pada fase ini siswa menerapkan pengetahuan pada situasi baru atau pada persoalan yang baru. Tahap ini siswa akan diminta untuk mengerjakan LKS.

Tahap selanjutnya pada model learning cycle $7 e$ yaitu evaluate. Tahap ini digunakan guru untuk menilai dan mengobservasi sejauh mana pemahaman siswa terhadap materi yang di pelajari sebelumnya. Pada tahap ini siswa diberika soal kuis dan siswa diminta untuk mengerjakan soal tersebut secara mandiri.

Kemamampuan penalaran siswa lagi-lagi lebih di asah pada tahap terakhir yaitu tahap extend, tahap ini mengharuskan siswa untuk dapat berfikir, mencari dan menjelaskan contoh lain penerapan konsep yang telah di pelajari dalam kehidupan sehari-hari. Lebih jauh lagi, dapat dikatakan bahwa kegiatan ini dapat merangsang siswa untuk mencari hubungan konsep yang telah dipelajari dengan konsep lainnya. fase extend meningkatkan keammpuan siswa untuk indikator menemukan pola/sifat dari gejala matematis /membuat generalisasi.

Berdasarkan data yang telah diperoleh dari hasil tes akhir siklus I, siklus II dan siklus III, hasil observasi dan hasil wawancara yang dilakukan terhadap subjek penelittian serta guru di kelas peneliti, peneliti menyimpulkan bahwa kegiatan pembelajaran di kelas X MIA-1 SMAN 9 Jakarta berjalan dengan sanagat baik dan sesuai dengan rencana yang telah di susun. Selain itu, tujuan dari tindakan untuk meningkatkan kemampuan penalaran matematis siswa juga tercapai.

Berdasarkan data hasil penelitian yang telah dipaparkan, dapat dikatakan bahwa kemampuan penalaran matematis siswa kelas X MIA-1 SMA Negeri 9 Jakarta mengalami peningkatan, baik secara keseluruhan siswa kelas X MIA-1, maupun keenam subjek penelitian.

Nilai rata-rata kemampuan penalaran matematis siswa kelas X MIA-1 pada siklus III sudah mencapai target indikator keberhasilan yang telah ditetapkan oleh guru dan participant observer, yaitu nilai rata-rata keseluruhan kelas meningkat sebesar 80,22\% dan berada pada kriteria B+. Sedangkan jumlah siswa yang memiliki nilai mencapai atau melebihi KKM juga mengalami peningkatan pada siklus III meningkat menjadi 27 orang siswa atau sebesar $84,37 \%$. Jadi dapat dikatakan bahwa pembelajaran matematika menggunakan model learning cycle $7 e$ sebagai upaya meningkatkan kemampuan penalaran matematis siswa mengalami keberhasilan dalam penerapannya pada penelitian ini.

\section{KESIMPULAN DAN SARAN}

\section{A. Kesimpulan}

Berdasarkan hasil pelaksanaan penelitian tindakan kelas upaya meningkatkan kemampuan penalaran matematis siswa dalam pembelajaran matematika menggunakan model pembelajaran learning cycle $7 e$ siswa kelas $\mathrm{X}$ MIA-1 SMAN 9 Jakarta dapat disimpulkan bahwa. Pembelajaran matematika mengguanakan model pembeajaran learning cycle 7e (elicit, engage, explore, explaine, elaborate, evaluate and extend) dapat meningkatkan kemampuan penalaran matematis siswa kelas X MIA-1 SMAN 9 Jakarta. Pernyataan tersebut berdasarkan hasil tes yang dilakukan pada setiap akhir siklus sebagai berikut:

- Secara umum rata-rata nilai tes akhir kemampuan penalaran matematis siswa kelas X MIA1 pada siklus I adalah 53,48 termasuk dalam criteria $\mathrm{C}+$, kemudian pada siklus II meningkat menjadi 68,03 (meningkat $15,47 \%$ ) termasuk dalam criteria B dan pada siklus III meningkat menjadi 80,22 (meningkat $28,44 \%$ ) termasuk dalam kriteria B+.

- Jumlah siswa dengan nilai kemampuan penalaaran matematisnya mencapai atau melebihi KKM juga mengalami peningkatan. Penelitian siklus 1 terdapat dua orang siswa atau sebesar $6,89 \%$, siklus II meningkat menjadi 8 orang siswa atau sebesar $24,24 \%$ dan pada siklus III meningkat menjadi 27 orang siswa atau sebesar $84,37 \%$.

- Rata-rata keterlaksanaan aktivitas guru pada pembelajaran matematika dengan model pembelajaran learning cycle $7 e$ pada siklus I adalah $82,35 \%$, sedangkan pada siklus II 
sebesar $91,2 \%$ dan pada siklus III sebesar 100\%. Ini berarti terjadi peningkatan aktivitas guru dari siklus I ke siklus II sampai ke siklus III sebesar 8,8\%.

\section{B. Saran}

Berdasrkan hasil penelitian, analisis dan pembahasan yang di uraikan, maka saran-saran yang berkaitan dengan pembelajaran matematika menggunakan model pembelajaran learning cycle $7 e$ dan diharapkan dapat bermanfaat serta dapat menjadi pertimbangan pada penelitian selanjutnya diampaikan sebagai berikut:

1. Model pembelajaran learning cycle $7 e$ telah berhasil meningkatkan kemampuan penalaran matematis siswa sehingga diharapkan model ini dapat diterapkan di sekolahsekolah lainnya.

2. Penerapan model pembelajaran learning cycle $7 e$ membutuhkan manajemen waktu dan pengelolaan kelas yang cukup, sehingga diperlukan perencanaan pembelajaran yang matang agar penggunaan waktu lebih efektif.

3. Hendaknya dalam pemberian soal-soal yang lebih variatif kepada siswa agar siswa dapat mengembangkan kemampuan penalaran matematisnya.

\section{DAFTAR PUSTAKA}

Einsenkraft , Arthur. (2003). Expanding The $5 E$ Model. Tersedia: http://emp.byui. edu/firestonel/bio405/readings/learning\%20models/expanding\%205e [diakses: 29 Mei 2015].

Hamalik, Oemar. (2009). kurikulum dan Pembelajaran, Jakarta: Bumi Aksara.

Pitriati. (2014). Pengaruh Penerapan Model Learning Cycle 7E Terhadap Peningkatan Kemampuan Penalaran dan Kemampuan Komunikasi Matematis Siswa SMP. Tesis. Bandung: UPI

Riyanto , Bambang. (2011). Meningkatkan Kemampuan Penalaran dan Prestasi Matematika Dengan Pendekatan Konstruktivisme Pada Siswa Sekolah Menengah Atas. Jurnal Pendidikan Matematika, Volume 5. No. 2. FKIP UNSRI. Tersedia: http://ejournal.unsri.ac.id/index.php /jpm/article /download /581/174 [diakses: 20 Juni 2015].

Shadiq, Fajar. (2004), Pemecahan Masalah, Penalaran, dan Komunikasi. Makalah. Disampaikan dalam Diklat Instruktur/ Pengembang Matematika Jenjang Dasar, Yogyakarta: PPG Matematika.

Wardhani , Sri. (2008). Analisis SI dan SKL Mata PelajaranMatematika SMP/MTs untuk Optimalisasi Tujuan Mata Pelajaran Matematika, Yogyakarta: Pusat Pengembangan dan Pemberdayaan Pendidik dan Tenaga Kependidikan Matematika,

Wijaya dan Dedi. (2010). Mengenal Penelitian Tindakan Kelas, Jakarta: Indeks.

Wulandari, Enika. (2011). Meningkatkan Kemampuan Penalaran Matematis Siswa melalui Pendekatan Problem Posing Di Kelas VIII A SMP Negeri 2 Yogyakart. Skripsi. Yogyakarta: UNY. 